\title{
Ambiguous Agricultural Drought: Characterising Soil Moisture and Vegetation Droughts in Europe from Earth Observation
}

\author{
Theresa C. van Hateren ${ }^{1,2, *\left(\mathbb{D}, \text { Marco Chini }^{1}(\mathbb{D}) \text { and Patrick Matgen }\right.}{ }^{1}$ and Adriaan J. Teuling ${ }^{2} \mathbb{D}$ \\ 1 Department of Environmental Research and Innovation, Luxembourg Institute of Science and Technology, \\ L-4362 Esch-sur-Alzette, Luxembourg; marco.chini@list.lu (M.C.); patrick.matgen@list.lu (P.M.) \\ 2 Department of Hydrology and Quantitative Water Management, Wageningen University and Research, \\ 6708 PB Wageningen, The Netherlands; ryan.teuling@wur.nl \\ * Correspondence: tessa.vanhateren@list.lu
}

Citation: van Hateren, T.C.;

Chini, M.; Matgen, P.; Teuling, A.J. Ambiguous Agricultural Drought: Characterising Soil Moisture and Vegetation Droughts in Europe from Earth Observation. Remote Sens. 2021, 13, 1990. https://doi.org/ $10.3390 /$ rs13101990

Academic Editor: Won-Ho Nam

Received: 13 April 2021

Accepted: 13 May 2021

Published: 19 May 2021

Publisher's Note: MDPI stays neutral with regard to jurisdictional claims in published maps and institutional affiliations.

Copyright: (c) 2021 by the authors. Licensee MDPI, Basel, Switzerland. This article is an open access article distributed under the terms and conditions of the Creative Commons Attribution (CC BY) license (https:// creativecommons.org/licenses/by/ $4.0 /)$.

\begin{abstract}
Long-lasting precipitation deficits or heat waves can induce agricultural droughts, which are generally defined as soil moisture deficits that are severe enough to negatively impact vegetation. However, during short soil moisture drought events, the vegetation is not always negatively affected and sometimes even thrives. Due to this duality in agricultural drought impacts, the term "agricultural drought" is ambiguous. Using the ESA's remotely sensed CCI surface soil moisture estimates and MODIS NDVI vegetation greenness data, we show that, in major European droughts over the past two decades, asynchronies and discrepancies occurred between the surface soil moisture and vegetation droughts. A clear delay is visible between the onset of soil moisture drought and vegetation drought, with correlations generally peaking at the end of the growing season. At lower latitudes, correlations peaked earlier in the season, likely due to an earlier onset of water limited conditions. In certain cases, the vegetation showed a positive anomaly, even during soil moisture drought events. As a result, using the term agricultural drought instead of soil moisture or vegetation drought, could lead to the misclassification of drought events and false drought alarms. We argue that soil moisture and vegetation drought should be considered separately.
\end{abstract}

Keywords: agricultural drought; soil moisture; NDVI

\section{Introduction}

Due to climate change and enhanced land-atmosphere feedback, droughts and their impacts will likely become more severe over the coming decades [1-3]. Droughts are generally considered to be induced by a precipitation deficit relative to normal conditions, which, when persisting over longer time periods, results in insufficient water supply to meet the demands of both human activities and the environment [4]. As a result, the impacts of droughts can range from decreased crop yield and damage to ecosystems, to land subsidence, insufficient drinking water, and the disruption of transport.

To monitor and quantify drought across the terrestrial part of the hydrological cycle, numerous drought indices have been developed over the past decades. These can be divided into indices for the three main drought types [5]. Meteorological droughts are defined as a prolonged period with below-normal precipitation. These droughts are typically quantified with the Standardized Precipitation Index (SPI) [6], reflecting the current dogma that droughts are measured relative to the mean climate as well as the climate variability at that location.

Meteorological droughts can propagate into hydrological droughts [7], which entail below-normal (ground) water levels or river discharge [8], and are generally evaluated using e.g., reservoir levels, the Standardized Runoff Index, or the Streamflow Drought Index [4,9]. Lastly, agricultural droughts reflect droughts in the soil moisture. The few studies that provide explicit definitions of agricultural drought, agree that it concerns a 
soil moisture deficit severe enough to hamper vegetation growth, agricultural production, or crop yield $[5,10,11]$.

Other definitions exist (e.g., [12]); however, these also relate the soil water status to the (agricultural) vegetation state. Due to its direct relation to food production (through crop yield) and water management (through irrigation), agricultural drought is often the key focus of drought monitoring and forecasting.

In line with their definition, agricultural droughts have traditionally been quantified based on the soil moisture conditions in the root zone (e.g., [13-16]). The well-known and widely-used (e.g., [17,18]) Palmer Drought Severity Index (PDSI) [19] calculates a simple water budget based on the monthly values of precipitation and the potential evapotranspiration, in combination with parameters that have been optimized to ensure similar PDSI values correspond to similar impacts on vegetation and crop yield even in different climate conditions.

The development of high-resolution land surface models applied at continental scales also allows a more physically-based alternative to PDSI, which can account for the local soil and vegetation properties. In other cases, ranked or standardized in situ or remotely sensed soil moisture observations have been used directly as an agricultural drought index (e.g., [20-22]). Helped by the readily available satellite observations of vegetation indices, such as NDVI, EVI, SIF, fPAR, NIRv, and VOD, other studies have focused on the use of these vegetation indices to quantify agricultural drought [23-25].

Similarly, [26] developed two separate indices for agricultural drought monitoring: one focused on soil moisture (SMDI), and the other on evapotranspiration (ETDI) deficits. In other studies, other combinations were made to quantify agricultural drought, such as precipitation, potential evapotranspiration, and soil moisture [27]. The current definition of agricultural droughts described earlier, i.e., a soil moisture deficit severe enough to hamper vegetation growth, thus, does not seem to be compatible with a single index that describes either its cause (soil moisture deficit) or its impact (hampered vegetation growth).

Whereas soil moisture and vegetation-based indices both aim to quantify agricultural drought, the relation between soil moisture and vegetation is characterized by considerable complexity and nonlinearity. This complexity was already acknowledged late in the nineteenth century, when [28] stated that "a drought affecting agriculture is a complex result of many considerations" [29]. Although combined indices have since been proposed as a solution to circumvent the nonlinear relation between soil moisture and vegetation [30-32], it is questionable whether agricultural drought and its impact can be adequately quantified by a single normalized index across climate gradients.

From the small scale to the continental scale, distinct water- and energy-limited soil moisture regimes can be identified [33], with the relation between soil moisture and the evaporative fraction often being represented by a bilinear relation [34]. Above the so-called critical moisture content, which is an absolute value of soil moisture, evapotranspiration and plant functioning will not be limited nor affected by a lack of precipitation.

In fact, in humid climates, increased incoming solar radiation during meteorological drought periods can even enhance evapotranspiration [35] often leading to positive anomalies in vegetation indices, relative to the mean conditions, despite relatively dry conditions [36-39], as illustrated in Figure 1.

We hypothesize that because of this duality in agricultural drought impacts, the use of the term agricultural drought is ambiguous, because vegetation impacts might depend on the absolute rather than relative soil moisture conditions, in a way that differs from a simple delayed response. The threshold behaviour associated with the "absolute" critical moisture content is clearly at odds with the current dogma that drought and its impacts should be expressed relative to the mean conditions. 


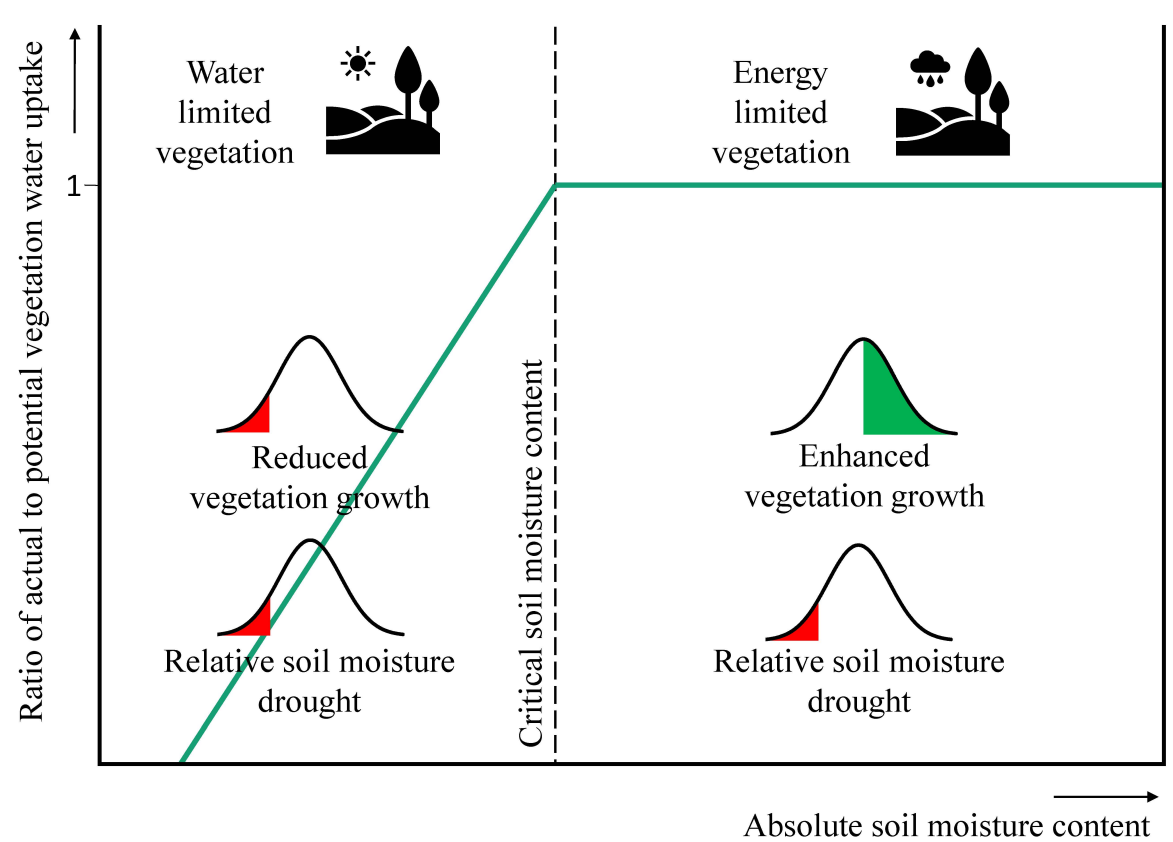

Figure 1. The ambiguity of agricultural drought. Normalised agricultural drought indices across a range of climates or mean soil moisture (SM) contents can show contrasting signs due to the nonlinearity between the soil moisture and vegetation water uptake. In water-limited (arid) climates, a normalised soil moisture drought (i.e., negative SM anomaly) will generally be accompanied by a drought in the vegetation indices (i.e., a negative growth anomaly). In humid climates, where the soil moisture generally does not limit the evapotranspiration and plant functioning, normalised soil moisture indices might indicate drought, whereas vegetation indices might show positive anomalies, as long as the soil moisture is above the absolute critical soil moisture content.

To address the issues surrounding the definition of agricultural drought, we aim to characterize the synchrony and similarity between droughts in the soil moisture and vegetation using readily available long-term (2000-2018) gridded data sets of precipitation, vegetation functioning, and remotely sensed soil moisture. We additionally aim to contribute to the debate on the use of drought indices (for agricultural drought in particular), and how routine global-scale Earth observation products can be used for this.

The relation between soil moisture and vegetation during drought periods has been studied [40-44], and significant correlations have been found, in addition to a lag between the soil moisture and vegetation response [41,42], especially in water-limited ecosystems [43]. Such lags are not expected in humid areas where the soil moisture content, though relatively low, might not decrease below the absolute critical moisture content.

Based on the aforementioned studies, and the concept of critical soil moisture [20,33], we hypothesize that the link between soil moisture and vegetation droughts is more direct in the water-limited Mediterranean region, whereas a more complex behaviour is expected in the more humid Northern Europe depending on the intensity and duration of the drought. Though a move toward the more unambiguous separate use of the two drought types has started over the past years (e.g., [45]), there are ongoing challenges related to the understanding, quantification, and operational monitoring of agricultural drought at larger (sub)continental scales that encompass a range of climate conditions.

Here, we investigate the relation between the surface soil moisture and vegetation drought, as observed in negative $(<-1)$ anomalies in soil moisture and NDVI from routine and widely-used Earth observation products. We investigate six widespread meteorological drought events that occurred over the past two decades in Europe, including the severe 2003 and, more recent, 2018 events, that occurred in water- as well as energy-limited regions. In addition, we critically evaluate the practice of using soil moisture to predict the observed agricultural drought (i.e., the vegetation impact) (e.g., [13,16,46-48]). 


\section{Data and Methods}

\subsection{Data}

Daily remotely sensed surface soil moisture (SM) data were obtained from the ESA Climate Change Initiative Combined soil moisture data set (ESA CCI SM v04.5) [49-51], with a $0.25^{\circ}$ resolution, spanning January 1979 until December 2018. The combined CCI algorithm includes the masking of uncertain soil moisture estimates, for instance in the case of frozen soil, water bodies, or dense vegetation [52], though masking can be insufficient at times [53]. The information contained in the satellite soil moisture data mainly contains the surface soil moisture content, rather than the root-zone soil moisture content [42], where the latter has a more direct impact on the vegetation performance.

Regardless, remotely sensed data were deemed the most suitable for this study due to the long time period and large spatial scale of the analysis, and the unavailability of root zone soil moisture measurements on such scales. Existing large scale root zone soil moisture data sets are either inferred from surface soil moisture using land surface models (e.g., [54-56]) or using water balance models (e.g., [57-59]). For a comparison between the performance of modelled soil moisture and satellite soil moisture products, we refer to [60].

As we used the surface soil moisture rather than the root zone soil moisture, the possibility exists that we overestimated any observed asynchrony between the water content and vegetation. This will be accounted for in the discussion of our results. The monthly precipitation data were collected from the NASA GPM IMERG final precipitation L3 data set with a $0.1^{\circ}$ spatial resolution [61,62] from June 2000 until February 2020.

The monthly Normalized Difference Vegetation Index (NDVI) data were gathered from the MODIS data set on a monthly timescale with a $0.05^{\circ}$ resolution, spanning February 2000 to December 2018 (MODIS MOD13C2) [63,64]. Although MODIS vegetation indices are available on a 16-day resolution, we opted for a monthly mean rather than a temporal composite, to have a more consistent sensing date throughout the data set.

In addition to the NDVI- a measure for the amount of live green vegetation and, thus, the crop health [65] -numerous other products exist that reflect the vegetation water status and/or productivity. These include other indices based on optical (NIR, RED, and BLUE) imagery (e.g., NIRv and EVI) or on microwave data (e.g., VOD). Though each of these different indices might produce slightly different results in this analysis, their application should not affect the fundamentally different response of the soil moisture and vegetation to meteorological drought.

Soil moisture and vegetation data were spatially and temporally resampled to the lowest spatial and temporal resolution and time span of both data sets, resulting in a monthly $0.25^{\circ}$ resolution from 2000 to 2018, and cropped to our European study area $\left(11^{\circ} \mathrm{W}-45^{\circ} \mathrm{E}, 35-72^{\circ} \mathrm{N}\right)$. On this time scale, we assumed that large-scale patterns in both the soil moisture and vegetation would remain similar, although lags between the surface soil moisture and vegetation patterns were expected [22] due to travel time toward the root zone. The main vegetation evolution occurs on a monthly timescale, not on a day-to-day basis, as near-surface soil moisture does. For comparison purposes, the monthly timescale, which is common in drought analyses, is, thus, more appropriate.

Both the soil moisture and NDVI data sets were then masked to only include grid cells where at least $80 \%$ of the area was covered by agricultural activities, to ensure any ambiguity based on land cover was removed from the equation. The 80th percentile was chosen as a trade-off between sufficient agricultural areas and a sufficient number of grid cells in the resulting mask. The 2018 ESA CCI land cover map [66] was used as the basis of the mask. The categories included in the present analysis are rainfed, irrigated, and mosaic cropland and grassland (IDs 10, 11, 12, 20, 30, and 130), resulting in the mask shown in Figure S6. All of the used data sets have been extensively validated (e.g., [60,67-70]); therefore, a validation was not conducted here. 


\subsection{Drought Event Selection}

To study the relation between negative soil moisture and vegetation anomalies, growing seasons where significant precipitation deficits occurred were selected based on the 6 month aggregated Standardized Precipitation Index (SPI6) [6]. The SPI6 was computed from the precipitation data (Section 2.1) contained in our reference period (2000-2018) using a Gamma distribution. The SPI6 in September of each year was compared, as that reflects the integrated precipitation deficit over a typical growing season (Apr-Sep).

A fixed growing season was chosen for the drought event selection, though we are aware that differences exist in the onset of the growing season, when high and low latitudes are compared. This will be accounted for in the discussion of the results. Interconnected grid cells over relatively large areas with a moderate to extreme precipitation deficit (SPI6 < -1) [71] were chosen, resulting in the six selected seasons/areas as indicated in Figure 2: the 2002 precipitation deficit over the Baltic states and north-western Russia [72], the 2005 event on the Iberian Peninsula [32] and the infamous 2003, 2015, and 2018 events over central Europe [73-75]. Due to the large north-south extent of the 2018 event, this event was split into two parts (hereafter referred to as "2018N" and "2018S"). Grid cells in these selected areas were then used for further analysis as discussed below.
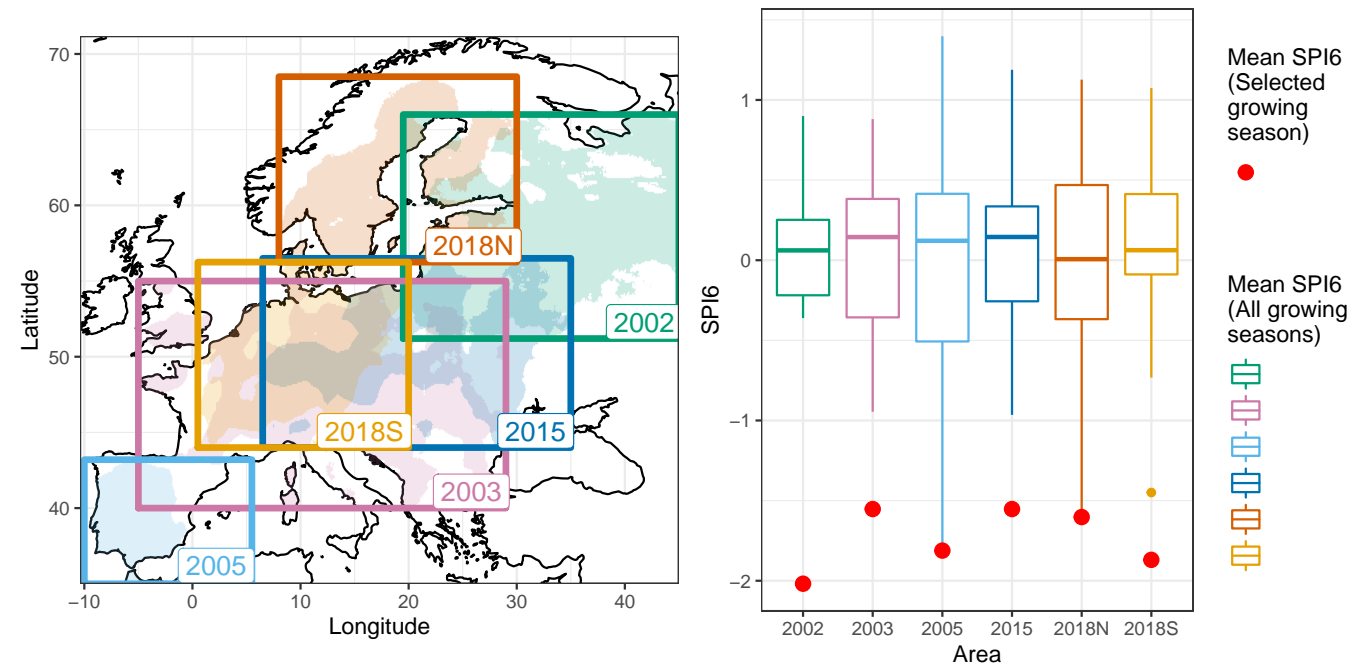

Figure 2. Properties of the selected summer droughts. Left: the location and spatial extent, right: SPI6 over the selected growing season (red), compared to the distribution of SPI6 in the remaining growing seasons for the same region.

\subsection{Analysis}

To allow for a fair comparison between anomalies of different variables, and to remove seasonal variations from the drought definition, the data were normalized by subtracting the long-term monthly mean from the SM/NDVI at each time step in a grid-wise manner, and subsequently dividing by the long-term (2000-2018) monthly standard deviation. This resulted in values between approximately -3 and +3 , indicating negative and positive anomalies, respectively, which can be directly compared with SPI6.

Other indices, such as the ESSMI [15] for soil moisture data, or the VCI [76] for NDVI data, are available and comparable to normalization; however, a more general approach was adopted here to increase the comparability of two different variables. We recognized anomalies in SM (SMA) and NDVI (NDVIA) below -1 as grid cells in soil moisture drought and vegetation drought, respectively, to include moderate, severe, and extreme droughts in the analysis [71]. To account for seasonality in the variables, data for each month of the year were taken separately, and grid cells with less than 7 data points were removed from the analysis.

After the data normalization, for agricultural grid cells belonging to each event, the percentage of the selected grid cells in drought was determined for each variable. Then, 
for each selected grid cell in each event and time step, the Pearson correlation between SMA and NDVIA was quantified. While correlation is useful for an overview of the similarity between two variables, it is not sensitive to bias or scale errors $[77,78]$. Skill scores, on the other hand, provide a more in-depth and well-rounded view on the use of soil moisture as a predictor for agricultural impact.

As soil moisture indices are often used as a proxy for vegetation drought (e.g., [13-16]), predictions using soil moisture drought are implicitly assumed to be skilful. Therefore, the number of Hits (H), Misses (M), Correct Rejections (CR), and False Alarms (FA) were determined for a case where the soil moisture drought (SMA $<-1$ ) was used to predict the vegetation drought (NDVIA $<-1$ ). These were used to compute five different skill scores, each highlighting a different aspect of the prediction accuracy. First, the Frequency Bias (FB) is given by:

$$
\mathrm{FB}=\frac{\mathrm{H}+\mathrm{FA}}{\mathrm{H}+\mathrm{M}}
$$

and expresses the difference between the mean drought frequencies. Next, the Frequency of Hits $(\mathrm{FOH})$ is a measure of discrimination that shows the fraction of forecasted vegetation droughts that were correct, which is given by:

$$
\mathrm{FOH}=\frac{\mathrm{H}}{\mathrm{H}+\mathrm{FA}}
$$

The Frequency of Misses (FOM) is given by:

$$
\mathrm{FOM}=\frac{\mathrm{M}}{\mathrm{H}+\mathrm{M}}
$$

and expresses the fraction of observed vegetation droughts that are incorrectly forecasted by the soil moisture drought. The Hanssen-Kuipers score (HK) [79] measures the ability of the soil moisture drought to discriminate between (or correctly classify) vegetation drought events and non-events:

$$
\mathrm{HK}=\frac{\mathrm{H}}{\mathrm{H}+\mathrm{M}}-\frac{\mathrm{FA}}{\mathrm{FA}+\mathrm{CR}} .
$$

Lastly, the Odds Ratio (OR) [80] is used to measure the strength of the association between soil moisture and vegetation drought:

$$
\mathrm{OR}=\frac{\mathrm{H} \cdot \mathrm{CR}}{\mathrm{FA} \cdot \mathrm{M}} .
$$

We refer to [81] for an overview of these skill scores as well as their advantages and disadvantages.

\section{Results}

A general check of the full data time series, including all land cover types, revealed that, during each event, asynchronies between the spatial patterns in the soil moisture and vegetation anomalies were widespread. Figure 3 shows the spread of different drought types during the 2015 growing season and serves as an illustration for these asynchronies, which occur in all green and purple grid cells (See Figures S1-S5 for other events).

Regionally more humid areas, such as mountain ranges and high latitude regions, can be easily distinguished by their relatively low Pearson correlations between the soil moisture and NDVI anomalies (Figure S7), in line with our hypothesis where we suggest that low correlations could be found in energy-limited regions, though other factors may play a role in this correlation, such as high local heterogeneity in the topography, soil moisture, and other vegetation types, as compared to the remaining region. Furthermore, correlations between the anomalies were low in April and generally increased toward September; however, in some areas, the correlations peaked in August. 


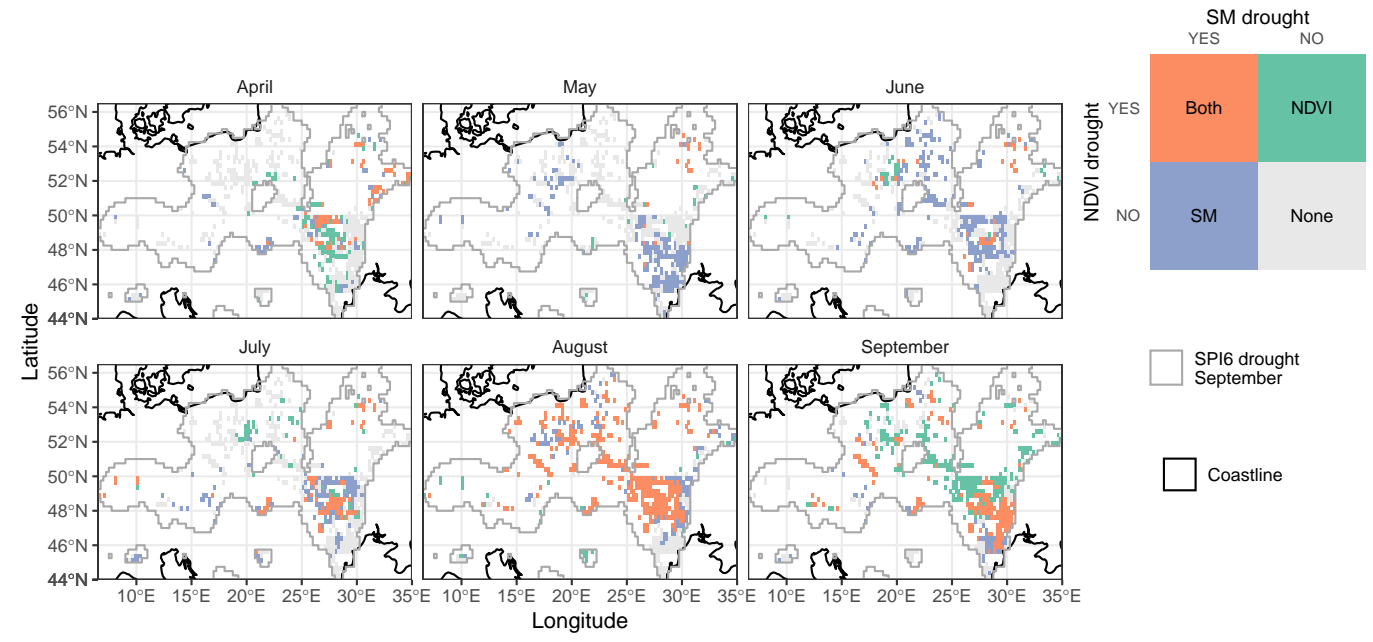

Figure 3. Synchrony between the soil moisture and vegetation droughts during the 2015 growing season in the agricultural grid cells. Note the asynchronous development of soil moisture and vegetation drought, with soil moisture drought dominating in May-June, and vegetation in April and September. Similar figures for the other drought events are included in the Supplementary Materials (Figures S1-S5).

Not all of the six studied events were equally affected by deficits in SM and/or NDVI. A comparison between drought extents using the fractions of the area affected by a soil moisture and/or vegetation drought is provided in Figure 4. The 2002, 2015, and both 2018 events are characterised by a clear overlap between the "NDVI" and "Both" lines, indicating that an area affected by a vegetation drought also has a soil moisture drought. Interestingly, in 2003 and 2005, some vegetation droughts occurred in the absence of a soil moisture drought.

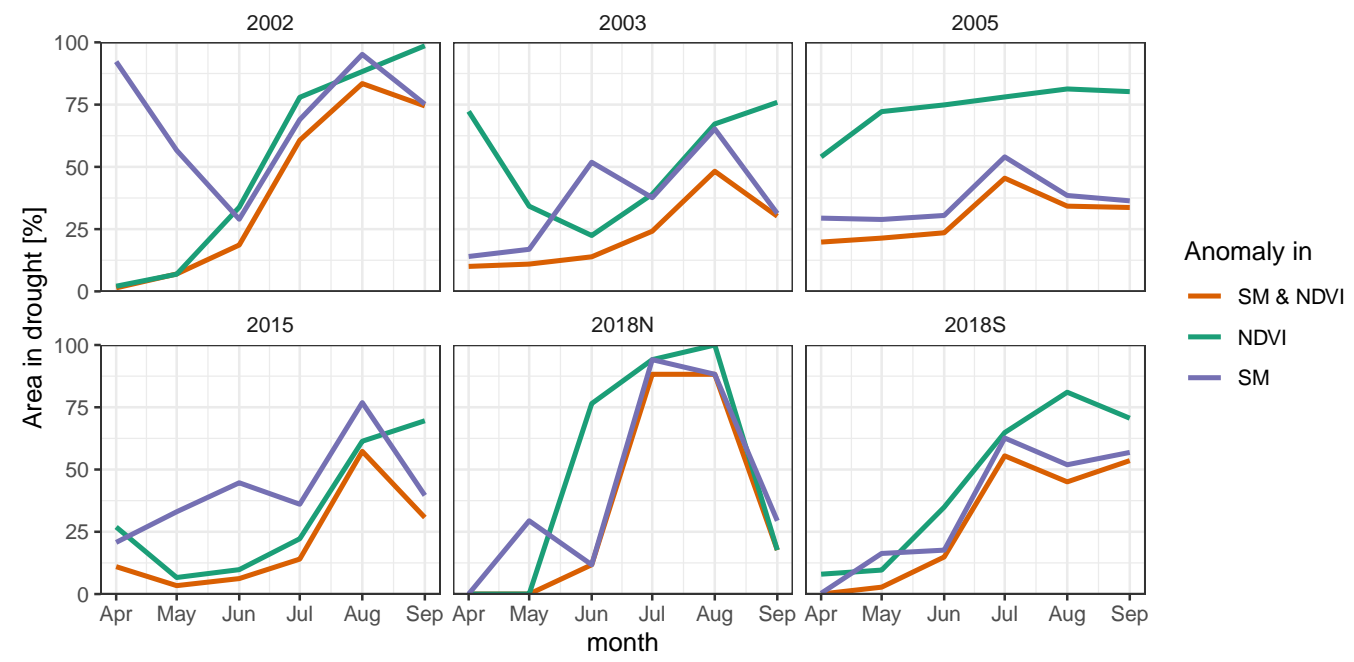

Figure 4. The growing-season evolution of the percentage of area in soil moisture and/or vegetation drought in the selected agricultural grid cells in each studied meteorological drought event. Panels show the six events, where the vegetation (NDVI, green) and soil moisture (SM, purple) grid cells in drought (defined as an anomaly <-1) are shown separately, as well as the percentage of grid cells affected by droughts in both variables simultaneously (orange).

Figure 5 shows the severity of each drought event for both the vegetation and soil moisture and the Pearson correlation between NDVIA and SMA. Asynchrony between the two variables is visible in the irregular shape of the arrows and the deviation of the linear regression from the 1:1 line. Generally, a delay can be distinguished between the negative SMA and NDVIA values. This delay was expected as discussed in Section 2.1. 
Interestingly, positive anomalies were more common in NDVIA than in SMA, showing that soil moisture droughts do not always negatively affect vegetation, and can sometimes even coincide with the opposite, i.e., positive, impacts in vegetation. High monthly correlations between SMA and NDVIA generally occurred later in the growing season as shown by yellow colours in Figure 5. For example, in the 2002 event, the NDVIA-SMA correlation increased from -0.45 in May to 0.68 in July, and correlations in the 2003 (2005, 2015, 2018N, and 2018S) event peaked in September (Sep, Aug, Sep, and Jul), at 0.51 (0.49, $0.68,0.77$, and 0.71$)$.

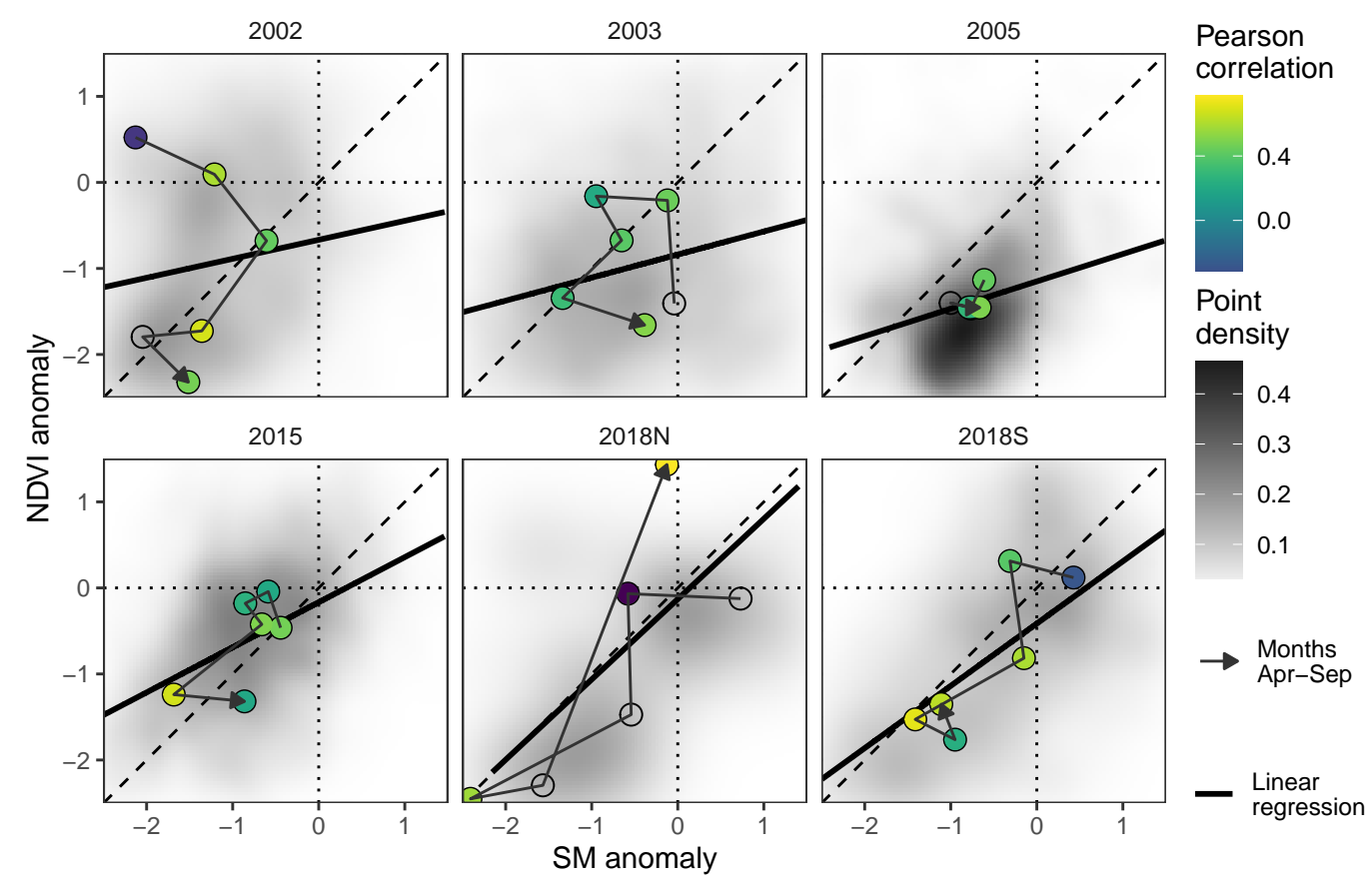

Figure 5. The relations between anomalies in the soil moisture (SM) and vegetation (NDVI). Panels show the six drought events, with both soil moisture and vegetation drought defined when the anomaly $<-1$. The point density in the background indicates the number of grid cells with a certain combination of anomalies in soil moisture and vegetation. The centroids of each month are chronologically connected with an arrow and shaded by the Pearson correlation in that month if $p \leq 0.05$.

Given the clear asynchrony and discrepancy in the soil moisture and vegetation under water-limited conditions, it is relevant to question how well soil moisture-based indices, such as the widely-used SSMI and PDSI, perform when targeting to quantify vegetation drought. The skill scores of the agricultural drought impacts, as reflected in NDVIA $<-1$ and as predicted using SMA $<-1$, are shown in Figure 6. From the low density of lines in the parts of the skill score plots shaded green, it is clear that the overall skill was rather low.

Similar to the Pearson correlation, the skill scores generally increased in August. Overforecasting, i.e., when more droughts were forecasted using soil moisture than there were droughts observed in vegetation, as seen in a FB $>1$, generally occurred in the beginning of the growing season, whereas underforecasting $(\mathrm{FB}<1)$ occurred near the end of the growing season. The respective increase and decrease in FOH and FOM show the result of the changing frequency bias.

The HK, showing the accuracy of events minus the accuracy of non-events, was rather stable throughout the growing season although it peaked in the second half as did the OR, which showed the number of correct forecasts. None of the drought events stood out in all of the skill scores. A sensitivity analysis showed that different thresholds for the drought selection and skill scores did not substantially change the results. 


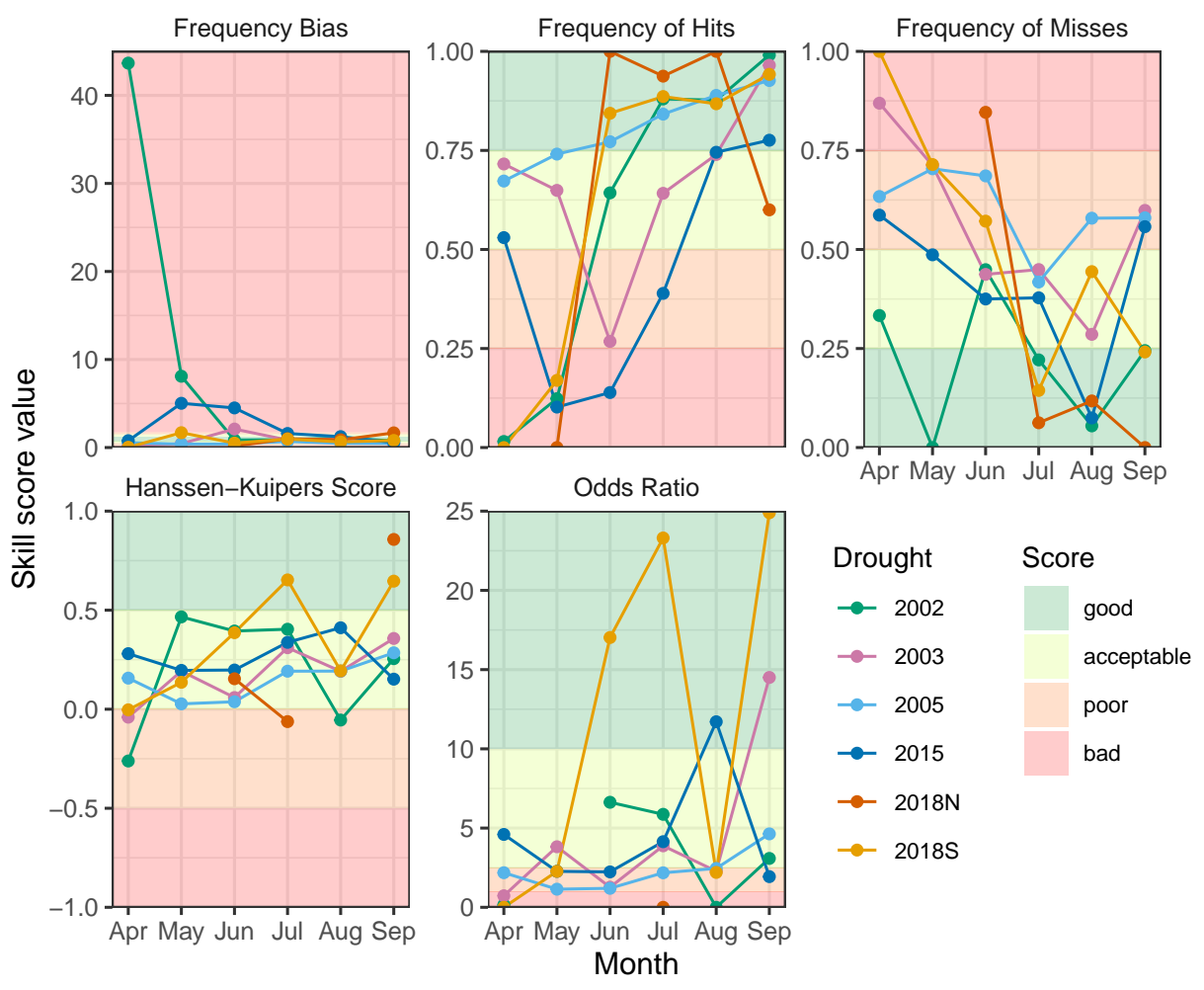

Figure 6. Skill scores for the soil moisture drought as a proxy for vegetation drought. The background colours indicate the quality of the skill scores (see Methods for their description), and the lines show different drought events.

\section{Discussion}

\subsection{Soil Moisture Regimes}

Our results showed that, in some cases, most notably during the 2003 and 2005 meteorological droughts, vegetation growth was not obviously limited by the current water content but possibly by other factors, such as the energy, heat stress, antecedent low soil moisture conditions, or pests and diseases. Since these events were located further south than most other selected events, energy limitations could be ruled out. Heat stress could well have been the limiting factor for vegetation, as well as antecedent soil moisture (Figures S9-S12).

Additionally, we showed, using a correlation analysis, that a general pattern in which NDVI remains largely unaffected by small anomalies in the SM content when vegetation is energy limited as is often the case at the start of the growing season. Under water-limited conditions, which are more likely to occur near the end of the growing season, higher correlations were found, consistent with the results of [36]. The southernmost 2005 event is the only event in which correlations peaked early in the season, which can be related to the water-limited conditions that are likely to occur earlier in the Mediterranean than in the geographic locations of the other events.

The extremely low correlations in the beginning of the 2002 event might also have been caused by the low temperatures that can occur early in the year in these latitudes, under which soil moisture estimates are highly uncertain [52,53], and the growing season might not have started. Finally, the skill scores were generally found to improve in the second half of the growing season; however, we expect the usefulness of end-of-season NDVIA prediction to be limited for agricultural purposes. These results do confirm our hypothesis that there is a more direct link between the soil moisture and vegetation state under waterlimited conditions, i.e., when the available water content is below the critical soil moisture, although this is only the case at the end of summer, instead of solely being related to geographical location. 


\subsection{Data Sets}

The complexity of agricultural droughts is not a local or regional issue but a global one and, thus, should be considered that way. While this study was performed over the European continent, it covers a range of climates found around the globe, from arid regions in the Mediterranean to boreal regions in northern Scandinavia. It is therefore expected that the behaviour will be similarly asynchronous in other regions. The limitations of this approach are on a local scale, rather than a global scale, due to the low spatial resolution of the analysis. Even though each data set was carefully selected based on the length, spatial resolution, and validation results over Europe, resulting in a selection of data sets best suited for this analysis, uncertainties are inherent to any type of data, and the results should, therefore, be interpreted with care.

In complex landscapes, high-resolution information can sometimes reveal a range of anomalies, even containing contrasting signs that are not visible at a coarser scale [82]. The normalising of the soil moisture data in this study can be criticised, because soil moisture data can show bimodality [83,84]. In addition, a data set length of 18 years can be considered short when compared to the traditional 30-year reference period as recommended by the WMO [85].

On the other hand, uncertainties due to areal properties are decreased, because the grid cell values are compared to other values of the exact same grid cell, while the resulting anomalies can easily be compared to other grid cell values. This, next to the possibility to fairly compare different variables, led to the decision to use a standard normalisation for both the vegetation and soil moisture data, regardless of the method's limitations.

In this research, we used available long-term satellite records of soil moisture and NDVI. Whereas current satellite soil moisture products are limited to the soil surface, a soil moisture drought assessment is ideally based on observations over the entire root zone. However, such observations are currently only available in several regional-scale observation networks [86]. By opting for surface soil moisture estimates rather than root zone soil moisture data, we performed this study using observations only.

On the other hand, the asynchrony between the surface soil moisture and vegetation index is likely larger than the asynchrony between the root zone soil moisture and vegetation, and thus asynchronies found here might be overestimated. For that reason, a skill score analysis was performed with a one month lag in the surface soil moisture (to account for the travel time to the root zone), which did not show large differences compared to the analysis presented in this paper (Figure S8).

\subsection{Separating Soil Moisture and Vegetation Droughts}

The inherently complex and nonlinear relation between soil moisture and vegetation status has important implications for drought monitoring where a distinction is traditionally made between meteorological, agricultural, and hydrological drought events. Though it might seem to be a logical step, based on our results, to redefine agricultural droughts from the traditional definition as a soil moisture drought, to be identical to vegetation droughts, this would disregard any information contained in the soil moisture anomalies.

For instance, it would be unclear whether any negative vegetation anomalies are caused by water stress, or by other factors, such as diseases or heat stress. We, therefore, argue that a distinction is necessary between soil moisture drought (reflecting water status) and vegetation drought (reflecting the impact of the drought on vegetation). This is particularly true when evaluating droughts across climate zones. The distinction between soil moisture drought and vegetation drought is important because shorter soil moisture droughts can even have a positive rather than negative impact on productivity, thus, risking the misclassification of drought events and false drought alarms.

\section{Conclusions and Outlook}

Agricultural droughts are generally quantified using anomalies in soil moisture; however, our results show that a clear asynchrony and discrepancies existed between the 
surface soil moisture drought and the impact of these droughts on vegetation. Occasionally, soil moisture droughts even coincided with positive anomalies in the vegetation. In some of the studied events, a vegetation drought could not be attributed to a soil moisture drought alone.

While the asynchrony of soil moisture and vegetation droughts is not a novel finding (e.g., [22]), the term agricultural drought is still being used as a synonym for soil moisture drought (e.g., [13,16,46-48]). To overcome this duality in the definition of agricultural droughts and to prevent false drought alarms, drought monitoring and prediction may benefit from a move away from the combined term agricultural drought (which can lead to confusion between soil moisture and vegetation effects) toward two separate terms: soil moisture drought and vegetation drought, each with their own indices and use in drought monitoring and forecasting.

Supplementary Materials: The following are available online at https:/ / www.mdpi.com/2072-429 2/13/10/1990/s1, Figures S1-S5: Illustrations of each drought event. Figure S6: Grid cells included in the analysis. Figure S7: Spatial overview of correlation between soil moisture and NDVI anomalies. Figure S8: Skill score analysis with a one month lag. Figures S9-S12: Average time series of soil moisture (anomalies) and NDVI (anomalies) prior to and during the drought events.

Author Contributions: Conceptualization, T.C.v.H., M.C., P.M. and A.J.T.; Data curation, T.C.v.H.; Formal analysis, T.C.v.H.; Funding acquisition, M.C., P.M. and A.J.T.; Investigation, T.C.v.H.; Methodology, T.C.v.H., M.C., P.M. and A.J.T.; Project administration, M.C., P.M. and A.J.T.; Software, T.C.v.H.; Supervision, M.C., P.M. and A.J.T.; Validation, T.C.v.H.; Visualization, T.C.v.H. and A.J.T.; Writingoriginal draft, T.C.v.H.; Writing-review \& editing, T.C.v.H., M.C., P.M. and A.J.T. All authors have read and agreed to the published version of the manuscript.

Funding: This research was funded by the Fonds National de la Recherche Luxembourg (FNR), grant no. PRIDE15/10623093 - HYDRO-CSI.

Data Availability Statement: The precipitation data were recovered freely from the NASA Global Precipitation Measurement (GPM) Integrated Multi-satellitE Retrievals for GPM (IMERG) “Final run" P data, available from 2000 to present upon registration via https: / / disc.gsfc.nasa.gov / datasets / GPM_3IMERGM_06/summary (accessed on 17 May 2021). Soil moisture data are freely available from 1978 to present from the ESA Climate Change Initiative (ESA CCI SM v04.5), after registration at https:/ / www.esa-soilmoisture-cci.org/ (accessed on 17 May 2021). Monthly NDVI data were recovered from the MODIS MOD13C2 product and are available for free on NASA's LP DAAC website (https://lpdaac.usgs.gov/products/mod13c2v006/, accessed on 17 May 2021). Land cover data are available on ESA's CCI land cover website: http: / www.esa-landcover-cci.org/ (accessed on 17 May 2021).

Conflicts of Interest: The authors declare no conflict of interest.

\section{Abbreviations}

The following abbreviations are used in this manuscript:

$\begin{array}{ll}\text { AD } & \text { Agricultural Drought } \\ \text { CR } & \text { Correct Rejections } \\ \text { FA } & \text { False Alarms } \\ \text { FB } & \text { Frequency Bias } \\ \text { FOH } & \text { Frequency of Hits } \\ \text { FOM } & \text { Frequency of Misses } \\ \text { H } & \text { Hits } \\ \text { HK } & \text { Hanssen-Kuipers score } \\ \text { M } & \text { Misses } \\ \text { NDVI (A) } & \text { Normalized Difference Vegetation Index (Anomaly) } \\ \text { OR } & \text { Odds Ratio } \\ \text { SM (A) } & \text { Soil Moisture (Anomaly) } \\ \text { SPI } & \text { Standardized Precipitation Index }\end{array}$




\section{References}

1. Rasmijn, L.M.; van der Schrier, G.; Bintanja, R.; Barkmeijer, J.; Sterl, A.; Hazeleger, W. Future equivalent of 2010 Russian heatwave intensified by weakening soil moisture constraints. Nat. Clim. Chang. 2018, 8, 381-385. [CrossRef]

2. Samaniego, L.; Thober, S.; Kumar, R.; Wanders, N.; Rakovec, O.; Pan, M.; Zink, M.; Sheffield, J.; Wood, E.F.; Marx, A. Anthropogenic warming exacerbates European soil moisture droughts. Nat. Clim. Chang. 2018, 8, 421-426. [CrossRef]

3. Teuling, A.J. A hot future for European droughts. Nat. Clim. Chang. 2018, 8, 364-365. [CrossRef]

4. Hayes, M.; Svoboda, M.; Wall, N.; Widhalm, M. The Lincoln Declaration on Drought Indices: Universal Meteorological Drought Index Recommended. Bull. Am. Meteorol. Soc. 2011, 92, 485-488. [CrossRef]

5. Tallaksen, L.M.; van Lanen, H.A.J. (Eds.) Hydrological Drought, 1st ed.; Developments in Water Science; Elsevier: Amsterdam, The Netherlands, 2004; Volume 84.

6. McKee, T.B.; Doesken, N.J.; Kleist, J. The relationship of drought frequency and duration to time scales. In Proceedings of the Eighth Conference on Applied Climatology, Anaheim, CA, USA, 17-22 January 1993.

7. Kumar, R.; Musuuza, J.L.; Van Loon, A.F.; Teuling, A.J.; Barthel, R.; Ten Broek, J.; Mai, J.; Samaniego, L.; Attinger, S. Multiscale evaluation of the Standardized Precipitation Index as a groundwater drought indicator. Hydrol. Earth Syst. Sci. 2016, 20,1117-1131. [CrossRef]

8. Seneviratne, S.I.; Nicholls, N.; Easterling, D.; Goodess, C.M.; Kanae, S.; Kossin, J.; Luo, Y.; Marengo, J.; McInnes, K.; Rahimi, M.; et al. Changes in Climate Extremes and their Impacts on the Natural Physical Environment. In Managing the Risks of Extreme Events and Disasters to Advance Climate Change Adaptation; Field, C.B., Barros, V., Stocker, T.F., Dahe, Q., Eds.; Cambridge University Press: Cambridge, UK, 2012; pp. 109-230. [CrossRef]

9. Shukla, S.; Wood, A.W. Use of a standardized runoff index for characterizing hydrologic drought. Geophys. Res. Lett. 2008, 35. [CrossRef]

10. Wilhite, D.A.; Glantz, M.H. Understanding the Drought Phenomenon: The Role of Definitions. Water Int. 1985, 10, 111-120. [CrossRef]

11. Panu, U.S.; Sharma, T.C. Challenges in drought research: Some perspectives and future directions. Hydrol. Sci. J. 2002, 47, S19-S30. [CrossRef]

12. IPCC. Glossary of terms. In Managing the Risks of Extreme Events and Disasters to Advance Climate Change Adaptation: A Special Report of Working Groups I and II of the Intergovernmental Panel on Climate Change (IPCC); Field, C.B., Barros, V., Stocker, T.F., Qin, D., Dokken, D.J., Ebi, K.L., Mastrandrea, M.D., Mach, K.J., Plattner, G.K., Allen, S., et al., Eds.; Cambridge University Press: Cambridge, UK; New York, NY, USA, 2012; pp. 555-564.

13. Sridhar, V.; Hubbard, K.G.; You, J.; Hunt, E.D. Development of the Soil Moisture Index to Quantify Agricultural Drought and Its "User Friendliness" in Severity-Area-Duration Assessment. J. Hydrometeorol. 2008, 9, 660-676. [CrossRef]

14. Bolten, J.D.; Crow, W.T.; Zhan, X.; Jackson, T.J.; Reynolds, C.A. Evaluating the Utility of Remotely Sensed Soil Moisture Retrievals for Operational Agricultural Drought Monitoring. IEEE J. Sel. Top. Appl. Earth Obs. Remote Sens. 2010, 3, 57-66. [CrossRef]

15. Carrão, H.; Russo, S.; Sepulcre-Canto, G.; Barbosa, P. An empirical standardized soil moisture index for agricultural drought assessment from remotely sensed data. Int. J. Appl. Earth Obs. Geoinf. 2016, 48, 74-84. [CrossRef]

16. Martínez-Fernández, J.; González-Zamora, A.; Sánchez, N.; Gumuzzio, A.; Herrero-Jiménez, C.M. Satellite soil moisture for agricultural drought monitoring: Assessment of the SMOS derived Soil Water Deficit Index. Remote Sens. Environ. 2016, 177, 277-286. [CrossRef]

17. Briffa, K.R.; Jones, P.D.; Hulme, M. Summer moisture variability across Europe, 1892-1991: An analysis based on the palmer drought severity index. Int. J. Climatol. 1994, 14, 475-506. [CrossRef]

18. Raible, C.C.; Bärenbold, O.; Gómez-navarro, J.J. Drought indices revisited-Improving and testing of drought indices in a simulation of the last two millennia for Europe. Tellus A Dyn. Meteorol. Oceanogr. 2017, 69, 1287492. [CrossRef]

19. Palmer, W.C. Meteorological Drought; U.S. Department of Commerce, Weather Bureau: Washington, DC, USA, 1965.

20. Peled, E.; Dutra, E.; Viterbo, P.; Angert, A. Technical Note: Comparing and ranking soil drought indices performance over Europe, through remote-sensing of vegetation. Hydrol. Earth Syst. Sci. 2010, 14, 271-277. [CrossRef]

21. Mozny, M.; Trnka, M.; Zalud, Z.; Hlavinka, P.; Nekovar, J.; Potop, V.; Virag, M. Use of a soil moisture network for drought monitoring in the Czech Republic. Theor. Appl. Climatol. 2012, 107, 99-111. [CrossRef]

22. Crow, W.T.; Kumar, S.V.; Bolten, J.D. On the utility of land surface models for agricultural drought monitoring. Hydrol. Earth Syst. Sci. 2012, 16, 3451-3460. [CrossRef]

23. Anyamba, A.; Tucker, C.J. Historical Perspectives on AVHRR NDVI and Vegetation Drought Monitoring. In Remote Sensing of Drought: Innovative Monitoring Approaches; Wardlow, B.D., Anderson, M.C., Verdin, J.P., Eds.; CRC Press: Boca Raton, FL, USA, 2012 ; pp. 23-49.

24. Hu, X.; Ren, H.; Tansey, K.; Zheng, Y.; Ghent, D.; Liu, X.; Yan, L. Agricultural drought monitoring using European Space Agency Sentinel 3A land surface temperature and normalized difference vegetation index imageries. Agric. For. Meteorol. 2019, 279, 107707. [CrossRef]

25. Buitink, J.; Swank, A.M.; van der Ploeg, M.; Smith, N.E.; Benninga, H.J.F.; van der Bolt, F.; Carranza, C.D.U.; Koren, G.; van der Velde, R.; Teuling, A.J. Anatomy of the 2018 agricultural drought in the Netherlands using in situ soil moisture and satellite vegetation indices. Hydrol. Earth Syst. Sci. 2020, 24, 6021-6031. [CrossRef]

26. Narasimhan, B.; Srinivasan, R. Development and evaluation of Soil Moisture Deficit Index (SMDI) and Evapotranspiration Deficit Index (ETDI) for agricultural drought monitoring. Agric. For. Meteorol. 2005, 133, 69-88. [CrossRef] 
27. Cao, Y.; Chen, S.; Wang, L.; Zhu, B.; Lu, T.; Yu, Y. An Agricultural Drought Index for Assessing Droughts Using a Water Balance Method: A Case Study in Jilin Province, Northeast China. Remote Sens. 2019, 11, 1066. [CrossRef]

28. Abbe, C. Drought. Mon. Weather. Rev. 1894, 22, 323-324.

29. Heim, R.R., Jr. A Review of Twentieth- Century Drought Indices Used in the United States. Bull. Am. Meteorol. Soc. 2002, 83, 1149-1166. [CrossRef]

30. Yurekli, K.; Kurunc, A. Simulating agricultural drought periods based on daily rainfall and crop water consumption. J. Arid. Environ. 2006, 67, 629-640. [CrossRef]

31. Sivakumar, M.V.K.; Stone, R.; Cesar Sentelhas, P.; Svoboda, M.; Omondi, P.; Sarkar, J.; Wardlow, B. Agricultural drought indices: Summary and Recommendations. In Agricultural Drought Indices, Proceedings of the an Expert Meeting, Murcia, Spain, 2-4 June 2010; Sivakumar, M.V.K., Motha, R.P., Wilhite, D.A., Wood, D.A., Eds.; WMO: Murcia, Spain, 2010; pp. 172-197.

32. Sepulcre-Canto, G.; Horion, S.; Singleton, A.; Carrao, H.; Vogt, J. Development of a Combined Drought Indicator to detect agricultural drought in Europe. Nat. Hazards Earth Syst. Sci. 2012, 12, 3519-3531. [CrossRef]

33. Denissen, J.M.C.; Teuling, A.J.; Reichstein, M.; Orth, R. Critical Soil Moisture Derived From Satellite Observations Over Europe. J. Geophys. Res. Atmos. 2020, 125. [CrossRef]

34. Seneviratne, S.I.; Corti, T.; Davin, E.L.; Hirschi, M.; Jaeger, E.B.; Lehner, I.; Orlowsky, B.; Teuling, A.J. Investigating soil moisture-climate interactions in a changing climate: A review. Earth Sci. Rev. 2010, 99, 125-161. [CrossRef]

35. Teuling, A.J.; Loon, A.F.V.; Seneviratne, S.I.; Lehner, I.; Aubinet, M.; Heinesch, B.; Bernhofer, C.; Grünwald, T.; Prasse, H.; Spank, U. Evapotranspiration amplifies European summer drought. Geophys. Res. Lett. 2013, 40, 2071-2075. [CrossRef]

36. Jolly, W.M.; Dobbertin, M.; Zimmermann, N.E.; Reichstein, M. Divergent vegetation growth responses to the 2003 heat wave in the Swiss Alps. Geophys. Res. Lett. 2005, 32. [CrossRef]

37. Teuling, A.J.; Uijlenhoet, R.; Hupet, F.; Troch, P.A. Impact of plant water uptake strategy on soil moisture and evapotranspiration dynamics during drydown. Geophys. Res. Lett. 2006, 33. [CrossRef]

38. Mastrotheodoros, T.; Pappas, C.; Molnar, P.; Burlando, P.; Manoli, G.; Parajka, J.; Rigon, R.; Szeles, B.; Bottazzi, M.; Hadjidoukas, P.; et al. More green and less blue water in the Alps during warmer summers. Nat. Clim. Chang. 2020, 10, 155-161. [CrossRef]

39. Kowalska, N.; Šigut, L.; Stojanović, M.; Fischer, M.; Kyselova, I.; Pavelka, M. Analysis of floodplain forest sensitivity to drought. Philos. Trans. R. Soc. B Biol. Sci. 2020, 375, 20190518. [CrossRef]

40. Zscheischler, J.; Orth, R.; Seneviratne, S.I. A submonthly database for detecting changes in vegetation-atmosphere coupling. Geophys. Res. Lett. 2015, 42, 9816-9824.

[CrossRef]

41. Chen, T.; de Jeu, R.; Liu, Y.; van der Werf, G.; Dolman, A. Using satellite based soil moisture to quantify the water driven variability in NDVI: A case study over mainland Australia. Remote Sens. Environ. 2014, 140, 330-338. [CrossRef]

42. Nicolai-Shaw, N.; Zscheischler, J.; Hirschi, M.; Gudmundsson, L.; Seneviratne, S.I. A drought event composite analysis using satellite remote-sensing based soil moisture. Remote Sens. Environ. 2017, 203, 216-225. [CrossRef]

43. Papagiannopoulou, C.; Miralles, D.G.; Dorigo, W.A.; Verhoest, N.E.C.; Depoorter, M.; Waegeman, W. Vegetation anomalies caused by antecedent precipitation in most of the world. Environ. Res. Lett. 2017, 12, 074016. [CrossRef]

44. Szczypta, C.; Calvet, J.C.; Maignan, F.; Dorigo, W.; Baret, F.; Ciais, P. Suitability of modelled and remotely sensed essential climate variables for monitoring Euro-Mediterranean droughts. Geosci. Model Devt. 2014, 7, 931-946. [CrossRef]

45. van Loon, A.F. Hydrological drought explained. WIREs Water 2015, 2, 359-392. [CrossRef]

46. Hao, Z.; AghaKouchak, A. Multivariate Standardized Drought Index: A parametric multi-index model. Adv. Water Resour. 2013, 57, 12-18. [CrossRef]

47. Chakrabarti, S.; Bongiovanni, T.; Judge, J.; Zotarelli, L.; Bayer, C. Assimilation of SMOS Soil Moisture for Quantifying Drought Impacts on Crop Yield in Agricultural Regions. IEEE J. Sel. Top. Appl. Earth Obs. Remote Sens. 2014, 7, 3867-3879. [CrossRef]

48. Martínez-Fernández, J.; González-Zamora, A.; Sánchez, N.; Gumuzzio, A. A soil water based index as a suitable agricultural drought indicator. J. Hydrol. 2015, 522, 265-273. [CrossRef]

49. Gruber, A.; Dorigo, W.A.; Crow, W.; Wagner, W. Triple Collocation-Based Merging of Satellite Soil Moisture Retrievals. IEEE Trans. Geosci. Remote Sens. 2017, 55, 6780-6792. [CrossRef]

50. Dorigo, W.; Wagner, W.; Albergel, C.; Albrecht, F.; Balsamo, G.; Brocca, L.; Chung, D.; Ertl, M.; Forkel, M.; Gruber, A.; et al. ESA CCI Soil Moisture for improved Earth system understanding: State-of-the art and future directions. Remote Sens. Environ. 2017, 203, 185-215. [CrossRef]

51. Gruber, A.; Scanlon, T.; Schalie, R.v.d.; Wagner, W.; Dorigo, W. Evolution of the ESA CCI Soil Moisture climate data records and their underlying merging methodology. Earth Syst. Sci. Data 2019, 11,717-739. [CrossRef]

52. Scanlon, T.; Pasik, A.; Dorigo, W.; De Jeu, R.A.M.; Hahn, S.; van der Schalie, R.; Wagner, W.; Kidd, R.; Gruber, A.; Moesinger, L.; et al. ESA Climate Change Initiative Plus-Soil Moisture: Algorithm Theoretical Baseline Document (ATBD); Technical Report D2.1 Version 04.7; Earth Observation Data Centre for Water Resources Monitoring (EODC) GmbH: Vienna, Austria, 2020.

53. van der Vliet, M.; van der Schalie, R.; Rodriguez-Fernandez, N.; Colliander, A.; de Jeu, R.; Preimesberger, W.; Scanlon, T.; Dorigo, W. Reconciling Flagging Strategies for Multi-Sensor Satellite Soil Moisture Climate Data Records. Remote Sens. 2020, 12, 3439. [CrossRef] 
54. Crow, W.; Tobin, K. GES DISC Dataset: Smerge-Noah-CCI Root Zone Soil Moisture 0-40 cm L4 Daily $0.125 \times 0.125$ Degree V2.0 (SMERGE_RZSM0_40CM 2.0), 2018. Available online: https://disc.gsfc.nasa.gov/datasets/SMERGE_RZSM0_40CM_2.0/ summary (accessed on 29 September 2020)

55. Beaudoing, H.; Rodell, M.; Getirana, A.; Li, B. Groundwater and Soil Moisture Conditions from GRACE Data Assimilation L4 7-Days $0.125 \times 0.125$ Degree V2.0, 2017; doi:10.5067/ASNKR4DD9AMW. Available online: https:/ / disc.sci.gsfc.nasa.gov/ datasets/GRACEDADM_CLSM0125US_7D_2.0/summary (accessed on 29 September 2020). [CrossRef]

56. Houborg, R.; Rodell, M.; Li, B.; Reichle, R.; Zaitchik, B. Drought indicators based on model assimilated GRACE terrestrial water storage observations. Water Resour. Res. 2012, 48. [CrossRef]

57. Owe, M.; De Jeu, R.A.M.; Holmes, T. Multisensor historical climatology of satellite-derived global land surface moisture. J. Geophys. Res. 2008, F01002. [CrossRef]

58. Crow, W. AMSR-E/Aqua Root Zone Soil Moisture (LPRM) L3 1 Day $25 \mathrm{~km} \times 25 \mathrm{~km}$ Descending and 2-Layer Palmer Water Balance Model V001. 2012. Available online: https:/ / disc.gsfc.nasa.gov/datacollection/LPRM_AMSRE_D_RZSM3_001.html (accessed on 29 September 2020).

59. Bauer-Marschallinger, B.; Paulik, C.; Hochstöger, S.; Mistelbauer, T.; Modanesi, S.; Ciabatta, L.; Massari, C.; Brocca, L.; Wagner, W. Soil Moisture from Fusion of Scatterometer and SAR: Closing the Scale Gap with Temporal Filtering. Remote Sens. 2018, 10, 1030. [CrossRef]

60. Beck, H.E.; Pan, M.; Miralles, D.G.; Reichle, R.H.; Dorigo, W.A.; Hahn, S.; Sheffield, J.; Karthikeyan, L.; Balsamo, G.; Parinussa, R.M.; et al. Evaluation of 18 satellite- and model-based soil moisture products using in situ measurements from 826 sensors. Hydrol. Earth Syst. Sci. 2021, 25, 17-40. [CrossRef]

61. Huffman, G.J.; Stocker, E.F.; Bolvin, D.T.; Nelkin, E.J.; Tan, J. GES DISC Dataset: GPM IMERG Final Precipitation L3 1 month 0.1 Degree $\times 0.1$ Degree V06 (GPM_3IMERGM 06), 2019; doi:10.5067/GPM/IMERG/3B-MONTH/06. Available online: https://disc.gsfc.nasa.gov/datasets/GPM_3IMERGM_06/summary (accessed on 18 March 2021). [CrossRef]

62. Huffman, G.J.; Bolvin, D.T.; Braithwaite, D.; Hsu, K.; Joyce, R.; Kidd, C.; Nelkin, E.J.; Sorooshian, S.; Tan, J.; Xie, P. Algorithm Theoretical Basis Document (ATBD) Version 06 NASA Global Precipitation Measurement (GPM) Integrated Multi-satellitE Retrievals for GPM (IMERG); Technical Report; National Aeronautics and Space Administration (NASA): Greenbelt, MD, USA, 2020.

63. Tucker, C.J. Red and photographic infrared linear combinations for monitoring vegetation. Remote Sens. Environ. 1979, 8, 127-150. [CrossRef]

64. Didan, K. MOD13C2 MODIS/Terra Vegetation Indices Monthly L3 Global 0.05Deg CMG V006 [Data Set]. 2015. Available online: https:/ /pdaac.usgs.gov/products / mod13c2v006/ (accessed on 16 July 2020). [CrossRef]

65. Ji, L.; Peters, A.J. Assessing vegetation response to drought in the northern Great Plains using vegetation and drought indices. Remote Sens. Environ. 2003, 87, 85-98. [CrossRef]

66. ESA. Land Cover CCI Product User Guide Version 2; Technical Report; European Space Agency: Paris, France, 2017.

67. Lahoz, W.; Blyverket, J.; Hamer, P. ESA Climate Change Initiative Phase II Soil Moisture-Product Validation and Intercomparison Report (PVIR) Revision 3; Technical Report 2.6; Earth Observation Data Centre for Water Resources Monitoring (EODC) GmbH: Vienna, Austria, 2018.

68. Navarro, A.; García-Ortega, E.; Merino, A.; Sánchez, J.L.; Kummerow, C.; Tapiador, F.J. Assessment of IMERG Precipitation Estimates over Europe. Remote Sens. 2019, 11, 2470. [CrossRef]

69. Lange, M.; Dechant, B.; Rebmann, C.; Vohland, M.; Cuntz, M.; Doktor, D. Validating MODIS and Sentinel-2 NDVI Products at a Temperate Deciduous Forest Site Using Two Independent Ground-Based Sensors. Sensors 2017, 17, 1855. [CrossRef] [PubMed]

70. Reinhart, V.; Fonte, C.C.; Hoffmann, P.; Bechtel, B.; Rechid, D.; Boehner, J. Comparison of ESA climate change initiative land cover to CORINE land cover over Eastern Europe and the Baltic States from a regional climate modeling perspective. Int. J. Appl. Earth Obs. Geoinf. 2021, 94, 102221. [CrossRef]

71. Lloyd-Hughes, B.; Saunders, M.A. A drought climatology for Europe. Int. J. Climatol. 2002, 22, 1571-1592. [CrossRef]

72. Rimkus, E.; Stonevicius, E.; Kilpys, J.; Maciulyte, V.; Valiukas, D. Drought identification in the eastern Baltic region using NDVI. Earth Syst. Dyn. 2017, 8, 627-637. [CrossRef]

73. Ionita, M.; Tallaksen, L.; Kingston, D.; Stagge, J.; Laaha, G.; Van Lanen, H.; Scholz, P.; Chelcea, S.; Haslinger, K. The European 2015 drought from a climatological perspective. Hydrol. Earth Syst. Sci. 2017, 21, 1397-1419. [CrossRef]

74. Hanel, M.; Rakovec, O.; Markonis, Y.; Máca, P.; Samaniego, L.; Kyselý, J.; Kumar, R. Revisiting the recent European droughts from a long-term perspective. Sci. Rep. 2018, 8, 9499. [CrossRef]

75. Buras, A.; Rammig, A.; Zang, C.S. Quantifying impacts of the 2018 drought on European ecosystems in comparison to 2003. Biogeosciences 2020, 17, 1655-1672. [CrossRef]

76. Kogan, F.N. Remote sensing of weather impacts on vegetation in non-homogeneous areas. Int. J. Remote Sens. 1990, 11, 1405-1419. [CrossRef]

77. Brier, G.W.; Allen, R.A. Verification of Weather Forecasts. In Compendium of Meteorology: Prepared under the Direction of the Committee on the Compendium of Meteorology; Byers, H.R., Landsberg, H.E., Wexler, H., Haurwitz, B., Spilhaus, A.F., Willett, H.C., Houghton, H.G., Malone, T.F., Eds.; American Meteorological Society: Boston, MA, USA, 1951; pp. 841-848. [CrossRef]

78. Murphy, A.H.; Epstein, E.S. Skill Scores and Correlation Coefficients in Model Verification. Mon. Weather. Rev. 1989, 117, 572-582. [CrossRef]

79. Hanssen, A.W.; Kuipers, W.J.A. On the Relationship between the Frequency of Rain and Various Meteorological Parameters; Technical Report 81; Koninklijk Nederlands Meteorologisch Instituut: De Bilt, The Nederlands, 1965. 
80. Stephenson, D.B. Use of the "Odds Ratio" for Diagnosing Forecast Skill. Weather. Forecast. 2000, 15, 221-232. [CrossRef]

81. Hogan, R.J.; Mason, I.B. Deterministic forecasts of binary events. In Forecast Verification: A Practitioner's Guide in Atmospheric Science, 2nd ed.; Joliffe, I.T., Stephenson, D.B., Eds.; John Wiley \& Sons, Ltd.: Hoboken, NJ, USA, 2011.

82. Buitink, J.; Uijlenhoet, R.; Teuling, A.J. Evaluating seasonal hydrological extremes in mesoscale (pre-)Alpine basins at coarse $0.5^{\circ}$ and fine hyperresolution. Hydrol. Earth Syst. Sci. 2019, 23, 1593-1609. [CrossRef]

83. Teuling, A.J.; Uijlenhoet, R.; Troch, P.A. On bimodality in warm season soil moisture observations. Geophys. Res. Lett. 2005, 32. [CrossRef]

84. Vilasa, L.; Miralles, D.G.; Jeu, R.A.M.d.; Dolman, A.J. Global soil moisture bimodality in satellite observations and climate models. J. Geophys. Res. Atmos. 2017, 122, 4299-4311. [CrossRef]

85. WMO. WMO Guidelines on the Calculation of Climate Normals; Technical Report WMO-No. 1203; World Meteorological Organization: Geneva, Switzerland, 2017.

86. Mittelbach, H.; Casini, F.; Lehner, I.; Teuling, A.J.; Seneviratne, S.I. Soil moisture monitoring for climate research: Evaluation of a low-cost sensor in the framework of the Swiss Soil Moisture Experiment (SwissSMEX) campaign. J. Geophys. Res. Atmos. 2011, 116. [CrossRef] 